慶應義塾大学学術情報リポジトリ

Keio Associated Repository of Academic resouces

\begin{tabular}{|c|l|}
\hline Title & Intermediate species absorbing in the 500-nm region in nonenzymatic pyridoxal catalysis. \\
\hline Sub Title & \\
\hline Author & $\begin{array}{l}\text { 松島, 美一(Matsushima, Yoshikazu) } \\
\text { 小島, 美佐(Kojima, Misa) } \\
\text { 永田, 佳子(Nagata, Yoshiko) }\end{array}$ \\
\hline Publisher & 共立薬科大学 \\
\hline Publication year & 1991 \\
\hline Jtitle & $\begin{array}{l}\text { 共立薬科大学研究年報 (The annual report of the Kyoritsu College of } \\
\text { Pharmacy). No.36 (1991.),p.81-81 }\end{array}$ \\
\hline JaLC DOI & \\
\hline Abstract & \\
\hline Notes & 抄録 \\
\hline Genre & Technical Report \\
\hline URL & https://koara.lib.keio.ac.jp/xoonips/modules/xoonips/detail.php?koara_id=AN00062898-0000003 \\
\hline
\end{tabular}

慶應義塾大学学術情報リポジトリ(KOARA)に掲載されているコンテンツの著作権は、それぞれの著作者、学会または出版社/発行者に帰属し、その権利は著作権法によって 保護されています。引用にあたっては、著作権法を遵守してご利用ください。

The copyrights of content available on the KeiO Associated Repository of Academic resources (KOARA) belong to the respective authors, academic societies, or publishers/issuers, and these rights are protected by the Japanese Copyright Act. When quoting the content, please follow the Japanese copyright act. 


\title{
Intermediate Species Absorbing in the 500-nm Region in Nonenzymatic Pyridoxal Catalysis.*
}

\author{
Yoshikazu Matsushima, Misa KoJima and Yoshiko Nagata \\ 松島美一, 小島美佐, 永田佳子
}

A key step in the action of almost all pyridoxal enzymes is the formation of a quinonoid species, in which the $\alpha$-carbon in a Schiff base (aldimine) is deprotonated. Several enzymes have been reported to exhibit an intense absorption band in the $500-\mathrm{nm}$ region of the spectrum, which has been ascribed to the quinonoid species. We reported previously that in methanolic solutions pyridoxal and ethyl alaninate with $\mathrm{Al}$ (III) gave an intense absorption band at $488 \mathrm{~nm}$, but not with divalent ions under the same conditions $[1]$.

We now report that the $500-\mathrm{nm}$ absorbing species was formed in the following nonenzymatic reactions in methanol. Isomerization between a ketimine from ethyl pyruvate and PM and an aldimine from ethyl alaninate and PL catalyzed by the $1: 1 \mathrm{Cu}$ (II) chelates of ethylenediamine (en), dipyridyl (dipy) and tripyridyl (tripy). The quinonoid species were stabilized in the ternary complexes such as $\mathrm{Cu}$ (II)-quinonoid-en. The fact that a similar ternary complex was not fully formed with diethylenetriamine (dien) should indicate the coplanarity of the quinonoid species.

* 本報告は “Enzymes Dependent on Pyridoxal Phosphate and Other Carbonyl Compounds as Cofactors”, eds. by T. Fukui, H. Kagamiyama, K. Soda and H. Wada, Pergamon, 1991, pp. 371-372. に発表. 